\title{
Yahya Kemal: Geleneği Geliştiren, Dönüştüren Şair
}

\author{
A Poet Who Improved and Transformed Tradition
}

Ö Z E T

Sanat eseri, bir toplumun değerler bütününün, kültürünün belli estetik formlarla ifade biçimidir. Güzel sanatların bir dalı olan şiir, kültüre ve estetik ölçülere dayanır. Şiir, toplumdaki değişmeleri belli bir mesafeden takip eder.

Osmanl toplumunun değerler değişimi döneminde yaşamış olan Yahya Kemal, bir taraftan yeniliklere açılırken diğer taraftan gelenekten beslenmiş bir şairimizdir. Klasik geleneğin etkilerinin en fazla görüldü̈̆̈̈̈ eseri ise "Eski Şiirin Rüzgâriyle" isimli şiir kitabıdır. Yazımız bu şiirlerin şekilden ziyade klasik şiirle örtüşen söyleyiş ve muhteva ortakliklarm, var olan imgeleri dönüştürmesini, kendisine özgü imajların ve devrin zihniyet yaptsinın etkilerini ortaya koymayı amaçlamaktadır.

A N A H T A R K E L İ M E L E R

Eski Şiirin Rüzgariyle, Yahya Kemal Beyatlı, Klasik şiir, gelenek, âhenk.

\section{A B S T R A C T}

Works of art, all of a society's values, culture is a particular form of aesthetic forms of expression. The poem, a branch of the arts are based on culture and aesthetic dimensions. Poetry, changes in society follows from a distance.

Yahya Kemal is a poet who lived during change the value of Ottoman society, one side opened to innovation; the other side, were fed by a poem of our tradition. Eski Şiirin Rüzgarlyle is a poetry book which seen most of the effects in the classic tradition. In this study, we showed with Yahya Kemal's poetry and classical poetry's similarity and differences in his poem. We have demonstrated the effect of poetry to convert the existing images, and assigns its own unique image of the structure of the mindset.

K E Y W O R D S

Eski Şiirin Rüzgariyle, Yahya Kemal Beyatll, clasiccal poetry, tradition, harmony.

\section{Giriş}

Sanat eseri, yaşanmış, paylaşılmış değerler bütününün, evrene, varlığa bakışın estetik ölçülerde ve belli formlarda yorumlanmasından ibarettir. Bu değer, ölçü ve formlar zamanla bir gelenek oluştururlar. Sanatın hemen her dalında oluşan bu gelenek, toplumların yaşadıkları zihinsel kırılmalara, değer yargılarındaki değişimlere paralel bir seyir izler. Var olan gelenek, ortak olunan yeni değerler sisteminin, benimsenen

Prof. Dr., Gazi Üniversitesi Gazi Eğitim Fakültesi Ortaöğretim Sosyal Alanlar Eğitimi Bölümü, Ankara. (yasaraydemir@yahoo.com,aydemir@gazi.edu.tr) 
yeni düşüncelerin oluşturduğu geleneğin yönlendirmesine açık hâle gelir. Ancak her zihinsel kırılmanın ve değer değişimlerinin uzunca bir zaman aldığ1 göz önüne alınırsa geleneğin de bütünüyle bir anda değişmesi beklenemez. Birkaç asır iki geleneğin yan yana gittiği, bir süre sonra da güçlü olanın yoluna devam edip diğerinin yerini güçlü olana bıraktığı bir süreç kaçınılmaz olur.

Yahya Kemal de Türk değerler sisteminin ve kültürünün değişme sürecinde yetişen şairlerimizdendir. Diğer alanlarda olduğu gibi gelenekli Türk şiiri de bu dönemde inkırazdadır. İki geleneğin mücadele ettiği bir dönemde Yahya Kemal, şiirlerinde bir taraftan kendi geleneğinden beslenirken diğer taraftan Batı gelenekli şiirin etkisinde kalmış ve bu çerçevede eserler vermiştir. Eski Şiirin Rüzgarıyle, onun, önemli ölçüde klasik gelenekten beslendiği şiirlerini içine alır. Bizim çalışmamız bu şiirlerin klasik kültürle olan münasebetini ele almayı amaçlamaktadir.

Yahya Kemal'in gerek Eski Şiirin Rüzgarıyle'deki şiirleri, gerekse diğer şiirleriyle ilgili şekil ve muhteva incelemesi, değişik çalışmalara konu olmuştur. Biz, çalışmamızda kısa değinmeler dışında buradaki şiirlerin şeklî (kafiye, redif, vezin, nazım şekli vs) tarafını konu edinmeyeceğiz. Yahya Kemal'in Eski Şiirin Rüzgarıyle'de klasik şiirin söyleyiş ve muhtevasındaki ortaklıklarını, şairin bu şiirlerde geleneğe kattığı yenilikleri, var olan imgeleri kullanmasını ve dönüştürmesini, kendine özgü imajlarını, devrinin siyasi ve sosyal anlayışının, zihniyet dünyasının şiire yansımasını konu edinecek ve nazirelerini zemin şiire göre değerlendirmeye çalışacağı.

\section{Geleneği Takibi}

Şekil, Teknik, Ses ve Konularda Geleneği Takibi

Yahya Kemal'e göre şiir güfteden önce bestedir. Onda derunî bir ahenk aranmalıdır. Şiirde nağme yoksa o şiir değil nesir olur (Kemal 1971: 5-7). Şiir, adeta şarap gibi insanı mest etmelidir. Şiir, iyi şair elinde baştan başa âhenk olur. Nağme duyulmazsa belagat olmaz:

Bir şi'r mest edince şarâb-ı ezel gibi

Her misraıla vehm olunur en güzel gibi 
Üstâd elinde ser-te-ser âhenk

Mizrâba ses verir kelimâtıyla tel gibi

Elhân duyulmadıkça belâgat girân gelür

Lâf u güzâftan mütehassil kesel gibi (YK, s.39)

Şiiri bu şekilde tanımlayan Yahya Kemal, birçok şiirinde geleneğin ses ve âhengini takip etmiş, sesle muhteva arasındaki ilişkiyi vezinle de desteklemiştir.

Elli bin atlı kılıç koymamak azmiyle kına

Dolu dizgin koşuyorlardı akından akına

dizelerinde tırıs giden atlıların düzenli koşma seslerini $(\mathrm{x} x--/ \mathrm{x} x--/ \mathrm{x}$ $\mathrm{x}$ - -/ $\mathrm{x}$ x -) verirken;

Bin atlı akınlarda çocuklar gibi şendik

Bin atl o gün dev gibi bir orduyu yendik

misralarında tercih ettiğ vezinle $(--x / x--x / x--x / x--)$ seke seke, güle oynaya savaşa giden serdengeçtileri anlatır. "İstanbul'u Fetheden Yeniçeriye Gazel" şiiri de muhteva-vezin-ses üçlüsünün güzel bir örneğidir:

Vur pençe-i âlîdeki şemşîr aşkına

Gülbangi âsmânı tutan pîr aşkına

Ey leşker-i müfettihül-elbâb vur bugün

Feth-i mübîni zâmin o tebşîr aşkına

Vur deyr-i küfrün üstüne rekz-i hilâl içün

Gelmiş bu şehsuvâr-ı cihangîr aşkına

Düşü̈n çelengi Rûmun eğilsün ser-i Frenk

Vur Türk'ü gönderen yed-i takdîr aşkına

Son savletinle vur ki açllsin bu sûrlar

Fecr-i hücûm içindeki tekbîr aşkına (YK, s.27-28)

Klasik şiirimizde arzu edilen ses-muhteva ilişkisi Yahya Kemâl'in bu şiirinde oldukça başarılı bir şekilde uygulanmıştır. Şiirde musikiye katkı yapan unsurların başında vezin gelir. Vezinle birlikte şairin muhtevayı dikkate alarak seçtiği sesler şiirin başarısını artırmıştır.

Vur pençe-i âlîdeki şemşîr aşkına

Gülbangi âsmânı tutan pîr aşkına 
Aruz vezninde medli okumaya müsait heceyi takip eden hece, sesli harfle başlıyorsa hece medli okunmayıp ulama yapılır. Ulama yapmamanın aruzda kusur oluşturacağı bilinmesine rağmen bazı şairler bunu kusur olmaktan çıkarıp bir âhenk unsuruna dönüştürürler. Gazelin kafiyesini oluşturan "-îr" heceleri önlerine gelen sessiz harfle medli okumaya müsait hâle gelir: Şemşîr, pîr, tebşîr, cihangîr, takdîr, tekbîr gibi. Şiirde medli okumaya müsait hece, takip eden hece sesli harfle başlamasına rağmen, şiir boyunca ulama yapılmadan okunmuş ve muhtevaya uygun vurgu ifadesine dönüştürülmüştür.

Veznin ilk tef'îlesi "mef'ûlü" ile başlayıp iki kapalı bir açık (- - x) heceden oluşmuştur. Bir savaşı anlatan şiir için mısra başında iki kapalı bir açık hece, vurma ve vurma şiddetini vermesi açısından önem arz eder. Şiirin mısra başlarındaki bu vurma sesi son tef'îlede medli okunarak yankılanmış gibidir. Askeri galeyana getirmek, şevkini artırmak veya işine konsantre olmasını sağlamak için şiddetli ve nida niteliği taşıyan seslere ihtiyaç vardır. Yahya Kemal'in bu şiirinde mısra sonlarındaki ilk bakışta aruz kusuru gibi görünen heceyi ulama yapmadan medli okuyuşu, bilinçli bir tercihtir. Şiir boyunca " $u$ ", " $\ddot{\mathrm{u}}$ ", " 1 " vokalleri ile " $n$ " sesinin tekrarı, şairin anlatmak istediği muhtevaya uygun seçilmiş seslerdir.

Şairin vezin tercihi ile metnin muhtevası arasındaki benzer bir ilişki, bir kahramanlık şiiri olan "Alp Aslan'ın Ruhuna Gazel"de de vardır. Burada tercih edilen vezin de iki kapalı bir açık (- - x) hece ile başlar. Birinci beyit ile diğer beyitlerin ikinci mısralarının üçüncü tef'îlelerinin son açık heceleri medle tamamlanmıştır. "İstanbul'u Fetheden Yeniçeriye Gazel"deki ses unsuru burada da kullanılmıştır:

İklîm-i Rûm'u tuttu cihangîr savleti

Târîh o işte gördü nedir şîr savleti

Tasvîr eder mi böyle şehinşâhı ey Kemâl

Şimşekten olsa şi'rde ta'bîr savleti (YK, s. 45-46) 


\section{Yahya Kemal'in Gelenekte İzini Sürdüğü Şairler}

Yahya Kemal'in gelenekte izini sürdüğü şairleri, bu şairlerle olan imaj ortaklıkları ve kimi şiirlere yazdığı nazireleri bağlamında değerlendirmek istiyoruz.

\section{Imaj ortaklıkları}

Yahya Kemal ile Nedîm aynı meşrepten şairlerdir. Her iki şair de denizi seyretmekten zevk alır:

Cihânda olmadı bir hisse-i verâsetimiz

Bebek koyunda temâş̧â-yı âbdan başka (YK, s. 23)

Zevkine aslâ doyulmaz seyrine gelmez ginâ

Ana dil-ber gibi dil bakdıkça olur mübtelâ

Seyr-i mehtâbı husûsâ pek temâşâ dil-güşâ

Ketm olur havz-ı musaffâ şîrden deryâ gibi (Nedim, Mr.44/4)

Klasik edebiyatımızda sevgilinin boyu genel olarak servi ve şimşâda benzetilir. Fıskiyeden fırlayan suya teşbihi ise ilk olarak Nedim'in şiirlerinde görülür:

Meger fevoûreden âb-ı letâfet sıçramış çıkmış

O rütbe kâmet-i ber-cesten ey şûh cihan vardır (Nedim, G. 42/6)

Nâzı âb etmiş de bir fevôare resm etmiş hayâl

İşe ol sudur atılmış kâmetin olmuş senin $\quad$ (Nedim, G. 72/2)

Sandım olmuş ceste bir fevvâre-i âb-ı hayât

Böyle gösterdi bana ol kadd-i müstesnâ seni (Nedim, G. 154/5)

Sevgilinin boyu kendisine benzetilen unsurlarla karşılaştırıldığında onlardan üstün gösterilir. Bu çerçevede hem Mesihî'nin hem de İshak Çelebi'nin divanlarında bulunan beyitte sevgili bahçeye salınarak varınca gül, bağa gölge salınca da servi utanır:

Var gülşene salın k'ola şermende şâh-ı gül

Gel bâğa sâye sal ki ola şermsâr serv

(Mesihî, K. 18/13; İshak, K. 10/13)

Yahya Kemal, Nedim'in beytindeki fıskiye ile sevgilinin boyunu görünce utanan servi imajını bir araya getirerek yeni bir terkibe ulaşmıştır. 
Beyte göre gül bahçesinde salınan sevgiliyi gören fıskıyeden çıkan su utanıp havuzun dibine düşer:

Fevvâre ka'r-ı havza düşer şerm-sâr olup

Baktıkca gül-sitânda hırâmân olan sana (YK, s. 25)

Yaşadığı anı dolu dolu yaşamak, devirden murad almak hem Nedim'in hem de Yahya Kemal'in ortak taraflarıdır. Nedim:

Gülelim oynayalım kâm alalım dünyâdan

Mâ-yı tesnîm içelim çeşme-i nev-peydâdan

Görelim âb-ı hayât akdı̆̆ın ejderhâdan

Gidelim serv-i revânım yürü Sa'd-âbâda (Nedim, Mr. 40/2)

derken Yahya Kemal de:

Her fasl-ı ömrü silsile-i nevbahâr kul

Zannetme ayş u işret içün başka çâ̆g olur

Dehrin devâmı âb-ı hayât içtiğincedir

Âdem bu dâr-ı köhnede bir kerre sâ̆ğ olur (YK, s. 89)

demektedir.

Lâle Devrinin tutkunu olan Yahya Kemal, Nedim'in:

Ol perî-rûyun cefâ-yı çeşm-i cellâdın demem

Derd-i aşkıyla Nedîmin âh u feryâdın demem

Tarz u tavrın söylesem mâni' değil adın demem

Gül yanaklı gülgülî kerrâkeli mor hâreli (Nedim, Mr. 42/5)

dizelerinde aklını başından alan ve bir türlü adını söylemediği güzele benzer bir söyleyişte, ama bir adım ileriye geçerek:

Ammâ yine hicrânla Kemâl andı̆̆ım âfet

Bağlarbaşı'nın goncası bir yosma civândır (YK, s. 86)

der.

Sevgili o kadar güzeldir ki, çemende irmaklar onu arar, bülbüller onu söyler. Sevgilinin meclisinde düşünceye dalıp ah edenler bulunur:

Çemende cûyveş bu cüst-cûlar hep senünçündür Miyân-ı bülbülânda güft-gûlar hep senünçündür

(Nâbî, G. 221/1) 
Sahn-ı bezminde nedir bu ser-fürûlar âhlar

Secdegâh-ı mezheb-i rindân mı etmiş Cem seni

(Âsaf, G. 159/3)

Yahya Kemal'in beytinde de benzer bir imaj vardır. Körfez'deki her âh ay yüzlü sevgili uğruna çekilmiştir:

Her âh bir hitâb idi Körfezde dün gece

Bin mâh içinde bir meh-i tâbân olan sana (YK, s. 25)

Şiirde söz konusu edilen hususu ses ve musikî ile de vermek gelenekli şairin hedeflerindendir. Bazı şairlerimiz kimi beyitlerinde veya mısralarında bunu başarmışlardır. Kendisi de bir sipahi olan Yahya Bey'in İran üzerine yapılan sefere ilişkin kaleme aldığ 1 kasidesindeki sert sessizlerin tercihi ile muhtevanın uygunluğu arasındaki ilişkinin bir benzerini de Yahya Kemal'in beytinde görüyoruz:

Çekelüm gün gibi ak sancă̆ ile şarka çeri

Kara toprağa karalum kıralum surh-seri

(Yahya Bey, K. 7/1)

Vur pençe-i âlîdeki şemşîr aşkına

Gülbangi âsmânı tutan pîr aşkına $\quad$ (YK, s. 26)

Klasik şiirimizde sevgilinin hangi güzellik unsuru anlatılıyorsa o idealize edilir. Yahya Kemal;

Ne serve bakmadadır şimdi gözlerim ne güle

O şîvekâr bu kâmette nev-civân olalı ～(YK, s. 37)

derken Mesihî, İshak Çelebi ve Hayâlî ile aynı duyguyu paylaşırlar:

Çeşmün ile kâmetün kaşun tururken ey sanem

Nergis ü serv ü hilâle bakmağa âr eyleyem

(Mesihî, G. 166/2)

Anmayam servi ger ol kâmet-i dil cûyı görem

Bakmayam sünbüle bu zülf-i semen bûyı görem

(İshak, G. 166/1)

Gülşen-i âlemde bir mevzûn nihâli gözleriz

Bakmazuz bir serve hadd-i i'tidâli gözleriz

(Hayâlî, G. 215/1) 
Gelenek içerisinde hem gerçek hem de mecaz anlamlarıla sıklıkla karşılaştı̆̆ımız sarhoşluk, Fuzulî ve Yahya Kemal'i aynı temennide buluşturur:

Hoş ol ki çekem dem-i ecel bâde-i nâb

Ser-mest yatam kabrde tâ rûz-ı hisâb

Gavgâ-yı kıyâmetde duram mest ü harâb

Ne fikr-i hisâb ola ne idrâk-i azâb (Fuzulî, Rubai 4)

Dünyâda bu iksîr ile mesûd olan ervâh

Ukbâda da ser-mest-i müdâm olsun erenler (YK, s. 79)

Hatta Yahya Kemal, caizse ilahî harâbâtta da dostlarla içmeye devam edilsin ister:

Câizse harâbât-ı ilâhîde de her şeb

Yârân yine rindân-ı kirâm olsun erenler (YK, s. 80)

Klasik edebiyatımızda "şevk" kelimesinin teşhis yoluyla kullanımina pek rastlanmaz. Bosnalı Sabit'in bir beytinde müjdeci olarak koşup gelen şevk, müjde ilacının neşesiyle raks ederek gelmektedir. Yahya Kemal'in beytinde ise devran Cem'in meclisinde döner; şevk de bu ritme sabaha kadar tekrar tekrar raks ederek katılır:

Ka'beden müjde-res-i şeok şitâbân geliyor

Neş'e-i dârû-yı tebşîr ile raksân geliyor (Sabit, K. 12/1)

Bezm-i Cemşî̀'de devrân kadehlerle döner

Şevk şeb-tâ-be-seher raks-ı mükerrerle döner (YK, s. 81)

Her ikisi de "sefer" üzerine kurgulanan Yahya Kemal ile Hayretî́nin beyitlerinde özne gönül, akıl ise âşık için çeldiricidir. Zımnen "Mümin müminin aynasıdır" hadisinden hareket eden Yahya Kemal'in beytinde de Hayretî́nin beytinde de manevî bir yolculuk vardır: Gönül bu yolculukta öncü durumundadır. Hayretî́nin beytinde bu rol aynı bedendeki gönüle, Yahya Kemal'in beytinde ise başka birisinin gönlüne verilmiştir:

Hudûd-ı aklı aşan manevî seferlerde

Yegâne meş'al-i îmân olur gönül gönüle (YK, s. 36)

Aklı koyup ışka uyaldan gönül ey Hayretî

Mülk-i fânîden bakâya intikâl itmek diler (Hayretî, G. 96/5) 
Genç Osman ve IV. Murad, Nef'î́nin övgüye layık bulduğu padişahlardır. Sultan Murad daha temkinli olmasına rağmen her ikisinin de gözü karadır. Belki de bu yüzden Nef'î onlara ayrı bir muhabbet besler. Her iki beytinde de kılıcını arşa asma imajı ve temennisi vardır:

Arşa as şimdengeri şemşîr-i cevher-dârmı

Anı ta'lîk etmeğe layık değil şeb'-i şidâd (Nef'î, K. 25/41)

Âferîn ey rûzgârm şehsüvâr-ı safderi

Arşa as şimdengeri tîg-ı süreyyâ-cevheri (Nef'î, K. 14/1)

Yahya Kemal, Sultan Selim'e olan muhabbeti ile Nef'î́nin iki kez tekrarladığ1 ve gerçekleşmesini istediği imgeyi Selim'in kişiliğinde hayata geçirir:

Pâmâl-i rahşı kıldı Acem tâc u tahtını

Tâ arşa astı tî̆̆ın Sultan Selìm Hân (YK, s.12)

Mesihî, Âsaf ve Yahya Kemal'in yaklaşık aynı kelime kadrosuyla kurgulanan beyitlerinde "hayal denizinde boğulmak", "hayal deryasinda dalgalanmak", "hayal gemisinde ufuklara yelken açmak" ve gemicilik terimleri, benzer bir hayalin küçük farklılıklarla tekrarı gibidir. Ancak, Yahya Kemal'in "hayal gemisiyle ufuklara yelken açmak" imgesi daha orijinal bir hayal görünüyor:

Garka-ı bahr-ı hayâl oldı duâ eyleyelüm

Bulmağa să̆ u esen keştî-i endîşe kenâr (Mesihî, K. 8/52)

Yine deryâ-yı hayâlin oluyor mevc-â-mevc

Açma keştî-i makale bu havâda yelken (Âsaf, K. 2/26)

Bir keştî-i hayâl ile âfâka yelken aç

Deryâyı dinle gör nice esrâr söylenür (YK, s. 87)

Kızılelma, Türk'ün ulaşmayı hedeflediği idealidir. Sabit ve Süleyman Fehîm gibi şairlerde de rastladığımız bu ideal, Yahya Kemal'in "Gedik Ahmet Paşa'ya Gazel" başlıklı şiirinde yaklaşık aynı anlamda kullanılır. Sabit'in beytinde "Kızılelma" ile "alma"; Fehîm'in beytinde "sîb" ile "Kızılelma", elmayı ifade eder. Yahya Kemal'in beytinde ise bu şekilde bir kelime oyunu yoktur. Ancak Kemal'in muhtevaya uygun olarak seçtiği sert sessizler, müstağni bir tavır ile Otranto'ya zafer edasıyla girişe eşlik eder: 
Beçi pâmâl idüp Romiyetü'l kübrâsını feth it

Kizil Elmâ'sin al kim emr-i elzem anı almadur (Sabit, K. 23/23)

Sîb-i gabgablı kız almak hevesiyle zâhid

Kızılelmâ'ya kadar gezdi Frengistân'ı (Süleyman Fehîm)

Çıktı Otranto'ya pür-velvele Ahmed Paşa

Tû̆ğlar varsa gerektir Kızılelmâ'ya kadar (YK, s. 72)

Duhter-i rez, üzüm kızı demektir. Mecazen şarap anlamına gelir. Şairler bu terkibi kullanırken kelimelerin bütün tedailerinden yararlanırlar. Şeyhülislam Yahya'nın "üzüm kızı", "gece", "yatmak" kelimeleriyle çağrıştırdığı çift anlamı, yaklaşık aynı kelime kadrosuyla Yahya Kemal tekrar eder. Hatta "damad olmak" kelime grubuyla bu çağrışımı daha da güçlü hale getirir:

Rez duhterini sâkî-i devrâna buldurun

Böyle şeb-i dirâzda gussayla yatmanuz (Ş. Yahya, G. 145/4)

Olsun serây-ı duhter-i rez hâbgâhımız

Pîr-i mugâne her gece dâmâd olun dedi (YK, s. 41)

Rint tipi, gelenekte bütün varını bir kadeh meye değişir. Hayretî, fani dünyadan geçmiş ama şaraptan asla vazgeçmemiştir. Yahya Kemal de alçak dünyayı dünyevîlere bahşederek Cem'in divanında serâzâd olmak ister:

Rind-i fânîler bu dünyâ-yı fenâdan geçdiler

Zâhidâ sanma şarâb-ı dil-güşâdan geçdiler (Hayretî, G. 114/1)

Dünyâ-yı dûnu bahşederek dünyevîlere

Dîvân-ı Cem'de rind-i ser-âzâd olun dedi (YK, s. 41)

Örneklerden hareketle Yahya Kemal'in Nedîm, Mesihî, İshak Çelebi, Nâbî, Âsaf, Yahya Bey, Fuzulî, Sâbit, Hayretî, Nefî, Fehîm gibi şairlerle imaj ortaklıkları yaptığı söylenebilir.

\section{Nazireleri ve Zemin Şiire Göre Değerlendirilmesi}

Yahya Kemal'in "Şâd Olmayan Gönül" gazeli (YK, s. 51-52) Şeyhülislam Yahya'nın matlaını iktibas yoluyla kaleme alınmış bir şiiridir. Gazelde vezin ve kafiyenin dışında bazı söyleyiş ortaklıkları da dikkati çekmektedir. Şeyhülislam Yahya'nın; 
Fevt itme nâ-murâdligun bâri neşvesin

Çün bâde-nûş̧-ı bezm-i murâd olmadun gönül (Ş. Yahya, G. 216/3)

beytine Yahya Kemal;

Sad hayf o sayd olunmayan âhûya dûş olup

Bir kerre neşve-yâb-ı murâd olmadın gönül

beytiyle karşılık vermiştir. Her iki beytte de murad alamamak esas olmakla birlikte çıkartılan sonuçlar farklıdır. Şeyhülislam Yahya, "Madem murad meclisinin kadehinden içemedin bari muradsızlığın neşesini kaybetme" derken, Yahya Kemal, sevgiliye ulaşamamasına ve muradın neşesini bulamamasına hayıflanır.

Şeyhülislam Yahya'nın;

Ol şâh-ı hüsnün iremedün pây-bûstna

Yahyâ gibi ki hâk-nihâd olmadın gönül (Ş. Yahya, G.216/5)

beytine Yahya Kemâl;

Gerdûne iğbirârmı hıfzeyledin müdâm

Afveyleyüp de rind-nihâd olmadın gönül

beytiyle karşıllı verir. Her iki beytte de istenilen tevazudur. Birisinde sevgilinin ayak toprağına ulaşmak, toprak yaradılışlı olmayı gerektirir. Diğerinde özlenen ise, kin tutmayıp kendisine kötülük yapanı affedecek rint yaradılışlı olmaktır.

Yahya Kemal, Nedim'in bir gazelini tanzir etmiştir.

Hatt-ı sebz olmuş bedîd ol gerden-i kâfûrdan

Ey aceb çımış zümürrüd ma'den-i billûrdan

Mey terâviş eyler emdikçe turunc-ı gabgabın

Şöyle sîr ol mest-i nâzım neş'e-i pür-zûrdan

Tâ kemergâhında gördüm mevc ururdu mutribın

Şöyle taşmış nağme-i ter kâse-i tanbûrdan

Dün çemende sevdiğgim mestâne geçdin bakmadın

Serv reftârın görüp başın salardı dûrdan

Mû-be-mû dikkatler etdim kıl kadar fark etmedim

Kaşlarm bi'llah begim dûşundaki semmûrdan 
Sâ'idin bûs eyledim gel gel amân ey dil sana

Tâze şeftâlü kopardım ol nihâl-i nûrdan

Nâ-tüvânım şöyle kim mecrûh olur cismim Nedîm

Geçse zîr-i sâye-i müjgân-ı çeşm-i mûrdan (Nedim, G. 107/7)

Mahurdan Gazel

Gördüm ol meh dûşuna bir şâl atup lâhûrdan

Gül yanaklar üstüne yaşmak tutunmuş nûrdan

Nerdübanlar bûsiş-i nermîn-i dâmânıle mest

Indi bin işveyle bir kâşâne-i făgfûrdan

Atladı dâmen tutup üç çifte bir zevrakçeye

Geçti sandım mâh-ı nev âyîne-i billûrdan

Halk-ı Sa'dâbâd iki sâhil boyunca fevc fevc

$V a^{\prime}$ de-i teşrîfine alkış tutarken dûrdan

Cedvel-i Sîm'in kenârından bu âvâzın Kemâl

Koptu bir fevvâre-i zerrîn gibi mâhûrdan (YK, s. 53-54)

Yahya Kemal'in "Mahurdan Gazel"inin Nedim'in zemin şiiri ile vezin, kafiye ve konu bakımından ortaklığı yanında her iki şiirde de kafiye ve redifi oluşturan "fağfûrdan", "dûrdan" ve "billûrdan" kelimeleri ortaklığın bir başka göstergesidir.

Nedim'in şiiri 7 beyit, Yahya Kemal'in şiiri ise 5 beyittir. İki şiir arasındaki beyit sayısı farkının getirdiği ilaveler dışında kompozisyon, yaklaşık aynıdır. Yüklendikleri fonksiyonları açısından bakıldığında ilk dört beytin birbiriyle paralel işlevlerinin olduğu görülür. Aynı paralellik son beyitlerde de dikkati çeker. Fark, iki şiirin beyit sayısından kaynaklanir.

$$
\text { Sevgili (1) mey+tanbur (2-3) }
$$

Sevgili (1) Merdiven+kayık (2-3) halk (4) Y. Kemal (5)

Yahya Kemal, gazelini Nedîm'in şiirinde geçen, onun şuhluğu ve zarafetini ifade eden kelimelerle ve yeni bir üslupla kurgulamıştır (Mazıoğlu 1994: 77). Yahya Kemal'in gazelindeki bütünlük, Nedim'in gazeline göre daha belirgindir. Hatta gazelin her bir beyti birbirini tamamlayan birer kareden oluşarak hareketli bir görüntü oluşturur. Buna göre sevgili omzuna lâhurdan bir şal atıp yavaş yavaş merdivenlerden 
iniyor. Eteğini kaldırarak küçük bir kayığa biniyor ve denize açılıyor. Sadabad halkı iki sahil boyunca onun gelişine uzaktan alkış tutuyor. Onu fark eden ve heyecanlanan aşığın beklenmedik bir anda kenardan neşeli avazı yükseliyor.

Yahya Kemal'in "Tazmin" başlıklı şiiri (YK, s. 61-62), genellikle II. Selim'e ait olduğu kabul edilen (Mazıoğlu 1994: 80);

Biz bülbül-i muhrik-dem-i şekvâa-yı firâkız

Âteş kesilür geçse sabâ gülşenimizden

beytine dört beyit ilavesiyle oluşturulan bir şiiridir. Zemin beyte hayal ve söyleyiş olarak yakın görünen:

Bir gün ser-i kûyından eğer geçsek o mâhın

Billâh o çemenzâr yanar dâmenimizden

beytindeki "eteğimizden çemenzâr yanar" ifadesinin zemin şiirin güzelliğini yakaladığını söylemek zordur. Aynı şekilde;

Bir şeb bizi sevk etse felek mev'id-i aşka

Vuslat tutuşur şûle-i pîrâhenimizden

beytindeki hayal güzelliğinin zemin şiirdeki hayalden geri kalmadığı söyleniyorsa da (Mazıoğlu 1994: 81) o hayale ulaşılabildiğini düşünmüyorum. Beyte göre felek, aşığı bir gün aşk vadine sevk etse, yani vuslata yöneltse, aşığın gömleğinin alevinden vuslat tutuşur. Hayaldeki "şûle-i pîrâhenden" vuslatın tutuşması hayli dolaylı gelmektedir. Vuslat, aşığın gömleğinden değil de belki nefesinden, gözlerinden tutuşsa veya âşı bu beklenmedik durum karşısında alev topuna dönüşse, sanki daha etkili ve makul bir anlatım olacaktır.

"Seyfi'ye Refâkat", Nedîm'in gazelini tahmistir. Nedim'in ilk beyti, anlatılan sevgilinin güzellik unsurlarıdır. Beytin önüne eklenen ilk iki mısra sevgiliye değil, meclise aittir. Diğer beyitlerin önüne konulan üçer mısra ise beytin anlamıyla kaynaşmış, anlam ve ahenge katkı sağlamıştir.

Hep eski âlem eski edeb meşrebimcedir

Tanbûr-ı Rûm lâhn-i Areb meşrebimcedir

Sîmîn ten üzre hâl-i zeheb meşrebimcedir

Sâk u sürîn ü gabgab u leb meşrebimcedir

Ser-tâ-be-pây hâsılı heb meşrebimcedir 
Hân-ı Elest'den beri mestim Hudâ alîm

Bir îtiyâddır bana mestî mine'l-kadîm

Bir tevbe-i mey etmeğe bin tevbe-i azîm

Bezm-i şarâbdan geçemem doğrusu Nedîm

İşret tabi'atımca tarab meşrebimcedir (YK, s. 105-06)

Yahya Kemal'in Neşâtî́nin Gazelini Tahmîs'i (YK, s.107-8) ile Sultan Reşad'ın Çanakkale zaferini konu alan gazelini (YK, s.107-8) tahmîsi, zemin şiirlere ahenk ve anlam katkısı yanında Türkçenin pürüzsüz kullanıldığ1 iki başarılı örnek olmuştur. "Râmî Mehmed Paşa'nın Gazel Matlaını Taştîr" (YK, s.111) de başarılı bir şiirdir. Aynı şeyi "Bâkî'nin Gazelini Taştîr"in bütün bentleri için söylemek zordur. Özellikle şiirin dördüncü bendinde; ilave edilen misralar, anlamca beyte tam uymadığ1 gibi beyitte bir parçalanma izlenimi de vermektedir:

Zühd ü salâha eylemeziz ilticâ hele

Âsâr-ı ittikâya bedel câm alıp ele

Dünyâda varımız yoğumuz vermişiz yele

Çekmekteyiz kavâfil-i uşşâka meş'ale

Tuttu egerçi âlem-i keoni fesâdımız (YK, s.112-13)

Zemin beyit taştir yerine tahmis edilseydi daha anlamlı ve güzel olurdu.

"Recaizâde Ekrem'in Mısraını Tazmin"de, klasik şairin tasvip etmediği bir kafiye problemi dikkatimizi çeker:

Sanırım ismini kuşlar heceler

Seni söyler seni dağlar dereler

Su çă̆ıldar kuzular kırda meler

Seni söyler seni dağlar dereler

Hep senin aşkm eserken serde

Hüsn ü ânın görünür her yerde

Gezdiğim duygulu vâdîlerde

Seni söyler seni dağlar dereler (YK, s. 122)

İlk bendin tekrar eden ikinci ve dördüncü misraı ile ikinci bendin üçüncü ve dördüncü misralarındaki kafiyeyi oluşturan sesler çoğul ekiyle sağlanmış, diğer misralarda ise kafiyeyi oluşturan sesler kelimenin aslından seçilmiştir. 
Yahya Kemal'in "Baharâbâd" başlıklı gazeli, ses, vezin ve redif olarak Nabî’nin "görmüşüz" redifli şiirini hatırlatır. Ancak şiir bir nazireden çok nakîzeyi andırır:

Çok da mağrûr olma kim meyhâne-i ikbâlde

Biz hezârân mest-i mağrûrun humârnn görmüşüz (Nâbî, G. 319/2)

Hayli şeb encümden efzûn câm-ı Cemler görmüşüz

Bezm-i meyden sonra subh-ı muhteşemler görmüşüz (YK, s. 99)

şeklinde karşılık bulurken son beyitlerinde de Nâbî hikemî üslubu ile makam ve mevkinin geçiciliğini; kimseye baki kalmayacağını anlatır. Yahya Kemal bununla ilgilenmeyip ancak ömrün zevkli tarafının bahse konu olabileceğini söyler:

Kâse-i deryûzeye tebdîl olur câm-ı murâd

Biz bu bezmün Nâbiyâ çok bâde-hârrn görmüşüz (Nâbî, G. 319/5)

Zikre lâyık bahsi ancak zevkidir ömrün Kemâl

Gerçi tâli'den nihayetsiz sitemler görmüusüz (YK, s. 100)

\section{Rintlik}

Birçok divan şairinde gördüğümüz rindane tavır, Yahya Kemal'in de şiirlerindeki en belirgin özelliğidir. "Ne Bildik Ne Bilmedik" başlıklı şiiri, kültürdeki rint tavrını fazlasıyla yansıtır. Ondaki rintlik, tasavvufun hoşgörüsüyle de birleşen bir rintliktir:

Biz gülden özge koklayacak sîne bilmedik

İşretten özge âdet-i dîrîne bilmedik

Dîdâr-ı Kibriyâ'yı kemâliyle gösteren

Şeydâ gönülden özge bir âyîne bilmedik

Mahsûl-i ömrü zevke fedâ eyledik müdâm

Mahfûz bir hazînede nakdîne bilmedik

Tiynetlerindedir sokan ef'î-i mel'anet

Hussâdı bî-günâh sayıp kîne bilmedik

Gaflet veya tegâfül edip bakmadik Kemâl

Gayz ü fesâd ü şerri ne bildik ne bilmedik (YK, s. 47-48)

Özellikle; 
Dî̀âr-ı Kibriyâ'yı kemâliyle gösteren

Şeydâ gönülden özge bir âyîne bilmedik

Tiynetlerindedir sokan ef $\hat{\imath}-i$ mel'anet

Hussâdı bî-günâh sayıp kîne bilmedik

Beyitleri, tasavvufun engin hoşgörüsüyle birleşen bir rintlik anlayışının yansımasıdır. Onun rintlik anlayışında klasik edebiyatın ârif ve kâmil insan tipi bulunur (Mazıoğlu 1995: 76). Mutasavviflarca da sembol olarak kullanılan gönül-ayna ilişkisi ve hakiki sevgilinin orada görüleceği anlayışı beyitte vurgulanmıştır. Yahya Kemal'in rintliği, kendisine haset edenleri bile günahsız sayıp kin gütmeyecek kadar geniş bir hoşgörüdür.

Yahya Kemal, ömür mahsulünü zevke feda eylemiş, geriye bir şey bırakmamıştır. Buradan kul olarak bir hayıflanma çıkartılabilir. Beyit bize Bakî̀nin;

Zühd u salâha eylemezüz ilticâ hele

Tutdı egerçi 'âlem-i keoni fesâdumuz (Bakî, G. 192/3)

beytini hatırlatırsa da Bakî́nin tok ve kavgacı üslubu onda yoktur. Bir derviş edasıyla samimice söylenmiş bir beyittir.

Yahya Kemal'in rintliği kendisine yapılanları affetmeyi gerekli kılar. Öyle ki bu klasik edebiyatımızda sürekli kendisiyle cedelleşilen felek olsa bile:

Gerdûne iğbirârını hıfzeyledin müdâm

Afveyleyüp de rind-nihâd olmadın gönül (YK, s. 52).

$\mathrm{O}$, başına gelen bütün sıkıntılara mutasavvıflar gibi "eyvallah" diyebilen bir anlayışa sahiptir.

Yahya Kemal'in "Veda Gazeli", rintliğin dinî ve mistik duygularla yoğrulmuş bir örneğidir (Mazıŏlu 1994: 76). "Tanbûrî Cemil'in Rûhuna Gazel" de aynı mistik ve dinî duyguları taşır: Şevk, Cem'in meclisinde kadehlerle dönen devrana raksıyla katılır, gönül çerağı ile haz aynaları tutuşur, makamlar arşa kadar açılır (Tanpınar 1982: 163; Horata 1985: 52), melekler gökten yere süzülerek bu dönüşe eşlik eder; her gelen rint bu mecliste zevke kanar ve canib-i rahmete bu kadehle döner. 


\section{Gelenekte Yenilikleri}

Devrinin Etkisiyle (Zihinsel Dönüşümle) Gelen Yenilikler

\section{Türk ve Türk Kahramanları}

Klasik edebiyatımızda Türk kelimesi, daha çok göz, gamze, ok, yay, akın ve yağmalama ile birlikte anılır; sevgilinin güzellik unsurlarının benzeyeni olur:

Şol âli çoh ala gözün gönlüm evin yağmaladı

Yă̆macı Türkün âdeti her kandasa yă̆ma imiş (Nesimî, G. 200/6)

Özellikle Balkanlarda ve Batı'da Türk kelimesi Müslüman anlamına gelir:

Bir hisârı var anun ism-i kabîhi Leşdür

Şöyle isilik olur sanki yanar âteşdür

Halkınun kimisi kâfir kimisi Türkeşdür

Bir yire vardı yolum adına dirler Dukakin (Ravzî, Mrb. 19/10)

XVIII. yüzyıldan itibaren değişmeye başlayan zihniyet, beraberinde gelen mahallileşme ve Türkleşme cereyanının (Özgül 2006: 290) sonucu Türk kelimesi siyasî bir anlam kazanır. İlâ-yı kelimetullah için kılıç sallayan, fethe giden Osmanlının gelenekli şiirinde ırkın öne çıtı̆̆ı bir anlayış yoktur. 1789 Fransız ihtilâlinin ateşlediği milliyetçilik hareketleri yeni ulus devletlerin oluşumuna zemin hazırlamış ve Türk kelimesi de gelenekteki anlamindan çıkarak siyasi bir terim haline dönüşmüştür. Yahya Kemal'in şiirinde de bu anlamıla kullanılmıştır:

Düşsün çelengi Rûmun eğilsün ser-i Frenk

Vur Türk'ü gönderen yed-i takdîr aşkına (YK, s. 28)

Türk kelimesi, "26 Ağustos 1922" başlıklı şiirde "Türk ordusu" tamlamasıyla tamamen siyasî anlamda kullanılmıştır. Ama Türk aynı zamanda İslam'in temsilcisidir:

Şu kopan firtına Türk ordusudur yâ Rabbî

Senin uğrunda ölen ordu budur yâ Rabbî

Tâ ki yükselsin ezanlarla müeeyyed nâmın

Gâlib et çünkü bu son ordusudur İslâm'ın (YK, s. 140) 
Yahya Kemal, Türk'ün İslam'ın temsilcisi oluşunu "Toplayış" başlıklı şiirinde (YK, s. 13-14) de tekrarlar. İran ile olan savaşı;

Tevhîd içün bu halkı döğüşmüş yiğitlerin

Yüz şehre rekzedildi muzaffer livâlarn

Bir kutba bağgl cümle gönüller bir olmalı

Mâdâm kâinâtta birdir Hudâları"

diyerek yorumlar.

\section{Memduhlar İçin Kullanılan Sıfatlarda Farklılıklar}

Yahya Kemal, Yavuz Sultan Selim'in Tebriz üzerine seferini anlattığ1 şiirinde "Yavuz'un Doğuyu ve Batıyı tahtına boyun eğdirerek ilahına bir devlet armağan edeceği" söylenir. Klasik kültürde "ilahina armağan etmek" gibi bir kullanım garip karşılanır.

Münkâd edip serîrine maşrıkla mağribi

Bir devlet armağân edecektir ilâhına (YK, s. 10)

"Söyleyişindeki Yenilikler" bahsinde de ifade ettiğimiz gibi Yahya Kemal, "Alp Aslan'ın Ruhuna Gazel" başlıklı şiirinde (YK, s. 45-46) Alp Aslan için "cedd-i ekberimiz" sıfatını kullanır:

Ey şanlı cedd-i ekberimiz âb-ı tîgınin

Bî-hadd imiş günȩ̧ gibi tenvîr savleti

Daha çok dinî bir terim olan "ekber" sıfatının Alp Aslan'ın vasfında kullanılmış olması, bir yandan Batının değerlerine ortak olan Türk toplumunun dini hassasiyetlerinin zayıflaması, diğer yandan da Türkçülük hareketlerinin etkili olmasıyla izah edilebilir.

Gelenekli şiirde toplumun değer yargılarına paralel bir anlatım dili tercih edilir. Bu, şair için de geçerlidir. Bizim inancımıza ve kültürümüze göre Hz. İsa tevhid dininin temsilcisidir. Dolayısıyla onun Muhammedî imanla nura gark olmasina gerek yoktur:

Gark-ı nûr olmalı îmân-ı Muhammed'le Firenk

Bu sefer Rim-papa'dan Hazret-i Îsâ'ya kadar (YK, s. 72) 


\section{Değişen Sevgili}

Yahya Kemal'in şiirlerindeki aşk, beşerîden ilâhîye, ideale doğru bir seyir takip eder. Bu durum onun sanatta ferdî olanı aşarak, ideale doğru gelişme arzusu (Tanpınar 1982: 167) ile izah edilir. "Zevkâbâd", "Derin Beste" gibi gazellerinde idealize edilen bir aşkı görmek mümkünken şarkılarının tamamında hatıralara dayalı, ayrılık temini vurgulayan somut, tasavvurî bir aşk ve sevgili imajı vardır.

Yahya Kemal'in şiirlerinde, gelenekli şiirin sevgili anlayışından sapmalar görülür. Sevgiliye yakışan keremse de cefa ve cevr yaraşır. Sevgili onun için adaletsiz olmalıdır:

Her ceor her cefâ yaraşır hüsn ü ânma

Bîdâd kıl keremse de şâyân olan sana (YK, s. 26)

Klasik şiirde sevgili ağlamaz; âşık ağlar. Hâlbuki Yahya Kemal'in beytinde Kasr-1 Şerefâbâd'a gelen sevgili orada geçirdiği güzel günleri hatırladıkça ağlar:

O şûh ağlar bugün Kasr-ı Şeref-âbâda geldikçe

O nûşânûş demler hâtır-ı nâşâda geldikçe (YK, s. 29)

Aynı durum, Yahya Kemal'in bir şarkısında da vardır; sevgiliden, beraber yaşanan günleri hatırlaması ve içlenmesi istenir:

Sen şarkıların durduğu bir lâhza kenârda

Yâdet ki sevişdikti ilâhî adalarda

İçlen! Soğuk ellerle hazîn alnını sar da,

Yâdet ki sevişdikti ilâhî adalarda

Ey şimdi elâ gözleri süzgün, sesi şakrak!

Kumral saçın üstünde görürsen iki üç ak

Çık kuytu hıyâbânlara, al bir kuru yaprak

Yâdet ki sevişdikti ilâhî adalarda (YK, s. 117)

Gelenekli şiirde âşığın penceresinden bakınca sevgili ahdine vefa göstermez. Buna mukabil âşığın sabretmekten başka bir seçeneği yoktur. Her ne kadar âşık;

Ağlatmayacaktın yola baktırmayacaktın

Ol va'deyi tekrâr-be-tekrâr unutma 
dese de sevgili tarafından dikkate alınmaz. Âşık da sevgiliye ancak sitem eder. 18. yüzylldan itibaren değişen insan tipine paralel olarak Fennî'nin; "Meşhûr meseldir âşıkı çok nâz usandırı" yahut Esrar Dede'nin: "Nâzı koy cânâ doygunum doygun" misraları değişen sevgili tipini haber verir (Özgül 2006: 317-18). Yahya Kemal'in:

Ahd-i vefâyı va'd-i tehî sanmasın ki dost

Gözden ıră̆ olunca gönülden ıră̆ olur (YK, s. 90)

beyti bu değişimin devamı sayılabilir.

\section{Var Olan İmajlarn Dönüş̧ürrmesi}

Klasik şiirde sevgilinin değil âşığın ağladığını; Yahya Kemal'in beytinde ise Kasr-1 Şerefâbâd'a gelen sevgilinin orada geçirdiği güzel günlerin hatırasına ağladığını belirtmiştik:

O şûh ă̆lar bugün Kasr-ı Şeref-âbâda geldikçe

O nûş̧ânûş demler hâtır-ı nâşâda geldikçe (YK, s. 29)

Bu beyit bize Mâhir'in:

Kanı ol gül gülerek geldiği demler şimdi

Ağlarım hâtıra geldikçe gülüş̧üklerimiz

beytini hatırlatmaktadır. Beyitte ağlayan âşı̆̆ın yerini sevgili alır ki, burada dönüşen bir durumdan/ gelenekten söz edilebilir.

Aynı durum şiirin son beytinde de redd-i matla olarak tekrar eder:

Hayâlinden bakar pûşî̀de-i evrâk olan havza

O şûh ă̆lar bugün Kasr-ı Şeref-âbâda geldikçe (YK, s. 30)

Yahya Kemal'in beytinde, uzaktaki ağaçlıklardan bülbülün feryadı gelince, rintler ve ney, sükut etmiştir:

Dururdu rindler dembeste ney dembeste vecdinden

A ğaçliklarda bülbül dûrdan feryâda geldikçe (YK, s. 30 )

Aşağıdaki beyitte ise bağda cümbüş vardır ve bülbülün sesi çıkmaz:

Bağda meyler içilir nâleler eyler neyler

Sesi çıkmaz acebâ bülbül uyur mı neyler (Lâedrî) 
Yahya Kemal, bir başka beytinde gül bahçesindeki melale paralel olarak bülbülü de lal eder:

Gülzâr pür-melâl ise bülbül de lâl ise

Siz müjde-i bahâr veren bâd olun dedi (YK, s. 42)

Klasik şiirde sevgilinin dudağı âb-1 hayattır ve âşığın hedefi ona ulaşmaktır. Son nefesine kadar bu ümitle yaşar. Aynı durum Yahya Kemal'in aşağıya alınan beytinde de vardır. Bu durum, son nefesini vermek üzere olan âşığın dudağından "îmâ-yı arzu dökülür" biçiminde ifade edilmiştir:

Hazan da erse Kemâl el çeker mi cânandan

Lebinden ol mehe îmâ-yı ârzû dökülür (YK, s. 92).

Şiirin mest etme özelliği, onun güzelliği ve orijinal oluşu ile ilgilidir. Hayretî́nin beytinde gülün şevkinden mest olan âşı/bülbül, her an bu şiiri tekrar ederek teselli bulur. Gülün şevki kadar olmasa da, ona teselli kaynağı olan şiirin mest edici bir tarafı vardır. Yahya Kemal'in beytinde ise insanı mest eden, doğrudan doğruya şiirin kendisidir:

Yâ meger kim şeok-ı gülden mest olupdur derd ile

Dem-be-dem bu şi'ri tekrâr eyleyüp eyler figân

(Hayretî, K. 15/19)

Bir şi'r mest edince şerâb-ı ezel gibi

Her misraıla vehm olunur en güzel gibi (YK, s. 39)

\section{İmajlarla Gelen Yenilikler}

Klasik şiirimizde sevgili idealize edilir. Ancak idealize edişte bile onun için seçilen sıfatların bir sınırı vardır. Mesela; sevgili için Yusuf'tan daha güzel denmez; genellikle Yusuf-ı sanî denir. En uç kıyaslamada bile Bakî̀nin:

Seni Yûsufla güzellikte sorarlarsa bana

Yûsuf'u bilmezin ammâ seni a'lâ bilürin (Bâkî, G. 369/2)

beytinde olduğu gibi makul bir tarafı vardır. Yahya Kemal, aşağıdaki beytinde sevgiliyi idealize ederken eğer müsaade edilseydi "Ondan başka ilah yoktur" derdim, noktasına getirerek sevgiliye bir ilâhe gö- 
züyle bakar. Burada dönemi kültürünün, özellikle de Yunan mitolojisindeki ilahelerin etkileri düşünülebilir.

Mesă̆ olaydı ĕger "lâ-şerîkeleh" derdim

Nazîri gelmedi âlemde hüsn ü ân olah (YK, s. 38)

Yahya Kemal'in "İnşirah Gazeli", mey teması etrafında şekillenmiştir. Klasik şairlerimizin de gerçek veya mecaz anlamlarında çokça rağbet ettiği mey, aşağıdaki beyitte farklı bir ifadeyle karşımıza çıkar. Beyitte tercih edilen kelime ve terimler dinîdir. "Ey Cem! Şeraitin ne mübarek bir nizamdır ki, haram olan meyin mübahlığına karar verir?" şeklinde düz yazıya aktarabileceğimiz beyit, Cem'in nizamıdır:

Şerîatın ne mübârek nizâmdir ey Cem

Harâm olan meyi tecvîz eder mübâha kadar (YK, s. 69 )

Klasik dönemde sanatçı, ortak değerlerin sınırlarını bilir ve eserini en azından iki farklı anlama gelebilecek şekilde kurgular. Benzer bir örneğine;

Aceb midir medeniyyet resûlü dense sana

Vücûd-ı mu'cizin eyler taassubu tahzir

(Tanpinar 1985: 196)

beyti ile 19. yüzyılda Şinasî́nin Mustafa Reşit Paşa medhiyesinde rastladığımız dinî terimleri din dışı alanlarda kullanma rahatlığı, değer yargıları değişmeye başlayan toplumun, şiir dilinin de değiştiğinin göstergesi olsa gerektir.

Yahya Kemal, şiiri musikînin hemşiresi sayar ve "Şiir musikîden başka türlü bir musikîdir." der (Kemal 1971: 135, 262). Her yanda akan rrmaklar bile musikî ile akar:

Her yanda mûsikiyle akar cûybârlar

Her bâd-ı subh ü şâm ile eşcâr söylenür (YK, s. 87).

"Üsküdar Vasfında Gazel"de:

Her lâhzası bir zemzeme-i Sûz-ı Dilârâ

Her sâati bir fasl-ı Beyâtî Araban'dır

dizeleri ile Yahya Kemal, "Üsküdar'da geçen her anın ve her saatin zeokini musikînin makamlarıyla ifade etmiştir." (Mazıoğlu 1994: 80). "Tanbûrî Cemil 
Bey'in Rûhuna Gazel"de "bütün kelimeler musikînin âhengi ile raksederek döner" (Mazıŏ̆lu 1994: 80).

Yahya Kemal'in hayranı olduğu ve meşrebine uygun bulduğu Lale Devrinden mülhem "Sene 1140" başlıklı şiiri (YK, s. 103-4), içinde yeni imgeleri barındırır. "Nermîn" sevgilinin ayağına "bûseden" ayakkabı giydirip düğün alayına "mehtâb"1 davet eder. İçinde bulunduğu hüzünler evinde Lale Devrini yad edip coşkusundan Sultan Ahmed'e neşve verir:

Nev-bahâr-ı vuslatın bassun deyu ilk ayına

Bûseden pâpûş giydirdim o nermîn pâyına

Kasr-ı Sa'dâbâd gülzâr-ı hümâyun-sâyına

Eyledim mehtâbı hem dâvet düğün alayına

...

Ey Kemâl eyyâm gördüm meslek-i şûhânede

Neşve verdim cûşişimden devr-i Ahmed Hân'e de

Dehrden bir kâm alup bir şeb bu mâtemhânede

Eyledim mehtâbı hem dâvet dü̈̆̈̈̈n alayına (YK, s. 103-04).

Kah Lâle Devrini, kah Yavuz Sultan Selim'i veya Alp Aslan'ı anlatırken o devri adeta yaşayan; vatan topraklarının büyük bir kısmının elden çıktığ 1 dönemlerde "bozgunda fetih rüyası" gören Yahya Kemal'in şiiri için zaman, önemli bir unsurdur. "Üsküdar Vasfında Gazel" şiirinde (YK, s.85-86):

Bir cûy-ı bahârın nagamâtıyla dolar gûş

Dil farkına varmaz ki akan cûy-ı zamandır

beytiyle zamanı akan bir ırmakla bağdaştırır.

Klasik edebiyatımızda mehtap ve mehtap sefası etrafında değişik benzetmeler, teşhisler yapılmıştır. Uyanmak ve mehtap kelimelerinin birlikte zikredildiği örnekler de vardır. 19. yüzyıl şairi Meşhurî́nin yaklaşık aynı kelime kadrosuyla kurguladığı:

Bahrm bu gece eyler isek biz n'ola seyrin

Yârân-ı safâ zevrak u mehtâb müheyyâ (Meşhurî, G. 6/4)

beyti olsa da, Yahya Kemal'in "Çubuklu Gazeli"ndeki "hayale dalan su" ile "mehtâb"1n uyanmaması gibi bir orijinalliği yoktur: 
Âheste çek kürekleri mehtâb uyanmasin

Bir âlem-i hayâle dalan âb uyanmasin (YK, s. 63)

\section{Tamamen Kendisine Özgü İmajları ve Söyleyişindeki Yenilikler}

Saki, işret meclislerinin olmazsa olmazlarındandır. Gelenekli şiirde saki de alımlıdır. O, sevgiliye yakın bir tavsifle anlatılır. Saki, Yahya Kemal'in aşağıya alınan beytinde ise daha farklı bir görüntüyle karşımıza çıkar. Anlatılan belki de bugünün meyhanesindeki biraz göbekli garsonu resmeden "sebû-endâm sâkî"dir:

Gülerdi taht-ı zerrîn üzre Cem gülşende güllerle

Sebû-endâm sâkîler elinden bâde geldikçe (YK, s. 29)

Yahya Kemal, "İstanbul'u Fetheden Yeniçeriye Gazel" başlıklı şiirinde:

Son savletinle vur ki açılsın bu sûrlar

Fecr-i hücûm içindeki Tekbîr aşkına (YK, s. 28)

"Fecr-i hücûm" ile hücumda gizli olan, onunla birlikte gelecek fetih müjdesini anlatır ki orijinal bir imge olmalıdır.

Klasik şiirimizde sevgili, güzel değili en güzeldir. Onun âşıkları arasinda sadece insanlar yoktur. Yahya Kemal'in;

Görmüşâyine-i sâfinda o serv-endâmı

Cûy gülşende bu rü'yâsımı hâlâ söyler (YK, s. 84)

beytinde de ırmak sevgilinin âşığıdır. Beyti farklı kılan, ırmağın servi endam sevgiliyi rüyasında görmesi ve hâla çemende bu rüyâsını anlatmasidir.

Gelenekli şair ne kadar varlıklı olursa olsun kendisi için mala mülke tenezzül etmeyen, müstağni bir profil çizer. Eğer mal ve mülkle övünecekse o, çoğunlukla kelam mülkünün veya suhen mülkünün malıdır. Onun için "Bakî kalan bu kubbede bir hoş sadadır". Miras bıraktığı grup da ehl-i suhen veya ehl-i kelamdır. Yahya Kemal'in beytindeki yenilik, mülk ü malı yoksa da beş on gazelle harap kalbini bırakacağı bir halkının olmasıdır:

Bu halka vakfedecek milk ü mâlimiz yoktur Beş on gazelle şu kalb-i harâbdan başka (YK, s. 23) 
Sevgiliyi öven dilden onu övecek nağme bulunmaz. Dolayısıyla Yahya Kemal onu, musikîye bırakmak ister. Çünki sevgili musikî kadar ince ve zariftir; insanı başka âlemlere götürür:

Tavsîfi mûsikîye bırakmak diler Kemâl

Bulmaz lisanda nă̆me senâhân olan sana (YK, s. 26)

Aşağıdaki beyitte farklı bir bağdaştırma dikkati çeker:

Dil uyur mest olarak yâr-ı dilârâ söyler

Gül susar şerm ederek bülbül-i şeydâ söyler (YK, s. 83)

Gelenekli şiirde sevgili ile gül, âşık ile de bülbül bağdaştırılır. Gülün utanması, bülbülün söylemesi, gönlün mest olması, sevgilinin konuşunca şeker gibi konuşması, ayrı ayrı düşünüldüğünde olağandır. Ancak sevgilinin söylediği yerde âşı̆̆ın mest olarak uyuması; bülbülün şakıdığı yerde de gülün utanması yeni bir bağdaştırmadır.

Kültürde mezarda Fatiha veya Yasin okunarak ölünün ruhuna hediye edilir. Yahya Kemal, Fatiha veya Yasin okumak yerine "Bu nevgazel"i bir Muhammedî beyan ve güzel bir hediye olarak annesinin kabrine gönderir:

Üsküp'de kabr-i mâdere olsun bu nev-gazel

Bir tuhfe-i bedî̀ ü beyân-ı Muhammedî (YK, s. 44)

Benzer bir durum, "Alp Aslan'ın Ruhuna Gazel” başlı̆̆ ve şiirinde de vardir (YK, s. 45-46).

Klasik edebiyatımızda Alp Aslan'a yazılmış bir medhiyeye rastlamadım. Varsa da dikkat çekecek bir varlık göstermiyor demektir. Yahya Kemal'in şiirinde baştan sona Alp Aslan'ın medhi yer almıştır. Bu şiirde klasik edebiyatımızın medhiye türünde yazılan şiirlerinde kullanılan terminoloji büyük oranda muhafaza edilmiştir. Ancak ilk defa kullanımı dikkatimizi çeken benzetmeler de vardır: "Cedd-i ekber"imiz gibi:

İklîm-i Rûm'ı tuttu cihangîr savleti

Târîh o işte gördü nedir şîr savleti

Titretti arş u ferşi Malazgird önündeki

Cûş u hurûş-ı rahş ile şemşîr savleti 
On yılda vardı sâhil-i Kostantiniyye'ye

Yer yer vatan diyârını teshîr savleti

Ey şanlı cedd-i ekberimiz âb- 1 tîgınin

Bî-hadd imiş güneş gibi tenvîr savleti

Tasvî̀ eder mi böyle şehinşâhı ey Kemâl

Şimşekten olsa şi'rde ta'bîr savleti (YK, s. 45-46)

Yahya Kemal'in "Çamlica Gazeli" (YK, s. 67-68), baştan sona fahriye havasında söylenmiş bir gazeldir.

Biz şi'ri böyle söyledik ă̆yâr söylesün

Hem dost söylesün bunu hem yâr söylesün

Benzer örneklerine Nef ' 1 ' de rastladı̆̆ımız bu gazelin;

Renk aldı özge âteşimizden şerâb u gül

Peymâne söylesün bunu gülzâr söylesün

beytindeki "şarap ve gülün rengini âşığın ateşinden alması" hayali ile;

Mırâb-ı tab'ımız sözü kalbetti besteye

Hem beste söylesün bunu hem kâr söylesün

beytindeki "mızrab-1 tabımız" terkibi, Yahya Kemal'e özgü bir orijinallik olarak görünüyor.

Yahya Kemal'in "Göztepe Gazeli"nin mahlas beyti olan;

Ey bî̀-vefâ Kemâl'e şemîm-i vefâ yeter

Bir hayli mısraında kalan bûy-ı kâkülün (YK, s. 66)

beytindeki "mısralarda kalan kakül kokusu", orijinal bir imge olmalıdır. Burada hayal derinliği olarak Nedim'in benzer imgelerinin varlığı hatırlanmalıdır;

Leblerin mecrûh olur dendân-ı sîn-i bûseden

La'lin öptürmek bu hâletle muhâl olmuş sana (YK, G. 2/7).

Beyitteki incelik, Yahya Kemal'in üslubuyla yakınlık arz eder. 


\section{Sonuç}

Yahya Kemal, "Eski Şiirin Rüzgarıyle"deki şiirlerinde klasik şiir geleneğimizin yolundan gitmiştir. Şiirlerinde aruzu tercih etmiş, Divan Edebiyatı nazım şekillerini kullanmıştır. Şiirlerine genellikle başlık koymayı tercih etmiştir. Nazireleri ile klasik kültürün nazire geleneğine yaslanmış, küçük istisnalar dışında büyük başarı sağlamıştır. Divan edebiyatının malzemesini ve dilini kendi üslubuyla yoğurarak yeni bir terkibe ulaşmıştır. Klasik kültürün rint tipini bütünüyle benimsemiş, şiirlerini rindane bir eda ile söylemiştir. Onun rintliği, tasavvufun hoşgörüsüyle iç içedir.

Yahya Kemal, şiirlerinde kelimelerin ahengine önem vermiş, şiirin musikisini konuya uygun seçtiği vezinlerle desteklemiştir. Türkçeyi aruza kolaylıkla tatbik etmiştir. Kelime seçiminde âhenkli seslere itina gösterirken vezinde bir aksama yaşanmamıştır.

Başta Nedîm olmak üzere, Şeyhülislam Yahya, Bâkî, Hayâlî, Yahya Bey, Fuzulî, Nef'î, Hayretî, Mesihî gibi şairlerle imaj ortaklıkları yapmış, Nedim, Şeyhülislam Yahya, Neşâtî, Sultan Reşat, Râmî, Bâkî gibi şairlerin şiirlerini tanzir, tahmis ve tazmin etmiştir. Divan şairlerinin kullandıkları bazı mazmunları benzer şekilde kullanırken, bir kısmını dönüştürmüş, bir kısminda da orijinal mazmunlar/imgeler ortaya koymuştur.

Yahya Kemal, şiirlerinde geleneği takip etmekle birlikte, kendi şairlik kudreti ve devri anlayışının bir sonucu olarak, gelenekte içi farklı doldurulan bazı kelime ve terimlere farklı anlamlar yüklemiştir. Büyük oranda klasik şairin idealize ettiği sevgili tipine yakın durmakla birlikte sevgilinin anlatımında tasvirî anlatımlara yer vermiştir.

\section{Kaynakça}

Akkuş, Metin (1993), Nef'î Divanı, Akçağ Yay., Ankara.

Aydemir, Yaşar (2007), Ravzî Divanı, Birleşik Yay., Ankara.

Ceylan, Ömür (1994), Âsaf (Mahmut Celaleddin Paşa) Hayatı Edebi Kişiliği ve Divanının Transkripsiyonlu Metni, Y. Lisans Tezi, Trakya Üni. Trakya. Çavuşoğlu, Mehmet (1977), Yahya Bey Divanı, İstanbul Üni. Edebiyat Fak. Yay., İstanbul. 
Horata, Osman (1985), "Eski Şiirin Rüzgarıyle ve Klasik Şiir Geleneğimiz" S. 65, Milli Ĕgitim, Ankara.

İpekten, Haluk (1990), Nailî Divanı, Akçağ Yay., Ankara.

Karacan, Turgut (1991), Bosnalı Alaeddin Sabit Divan, Cumhuriyet Üni. Yay., Sivas.

Kavruk, Hasan (2001). Şeyhülislam Yahya Divanı, MEB. Yay., Ankara.

Küçük, Sabahattin (1994), Bakî Divan Tenkidli Basım, AKM. Yay., Ankara.

Mazıoğlu, Hasibe (1994), "Yahya Kemal'de Eski Şiirin Rüzgarları", Doğumunun Yüzüncü Yılında Yahya Kemal, AKM Yay., Ankara, 71-88.

Mesihî, Divan (1995), Haz. Mine Mengi, AKM Yay., Ankara.

Meşhurî Divanı, (Haz. Yaşar Aydemir- Halil Çeltik), Basıma Hazır Çalışma.

Özgül, M. Kayahan (2006), Divan Yolu'ndan Pera'ya Selametle, Hece Yay., Ankara.

Tanpınar, Ahmet Hamdi (1985), 19'uncu Asır Türk Edebiyatı Tarihi, Çağlayan Kitabevi, İstanbul.

Tanpınar, Ahmet Hamdi (1982), Yahya Kemal, Dergah Yay., İstanbul.

Tarlan, Ali Nihat (1992), Hayâlî Divanı, Akçağ Yay., Ankara.

Yahya Kemal (1985), Eski Şiirin Rüzgarıle, İstanbul Fetih Cemiyeti Yay., İstanbul.

Yahya Kemal (1971), Edebiyata Dair, İstanbul Fetih Cemiyeti Yay., İstanbul.

Yahya Kemal (1986), Çocukluğum, Gençliğim, Siyasî ve Edebî Hatıralarım, İstanbul Fetih Cemiyeti Yay., İstanbul. 